\title{
Acute ischemic stroke due to painless long-segmental aortic dissection
}

Chuan Qin, MD, PhD, and Dai-Shi Tian, MD, PhD

Correspondence

Dr. Tian

tiands@tjh.tjmu.edu.cn

A man in his 60s with no obvious trauma experienced sudden left-sided weakness and confusion. At a local hospital at 4.5 hours after onset, a cranial CT was unremarkable; the initial diagnosis was acute ischemic large artery stroke. He was transferred to our stroke center for mechanical thrombectomy within 6 hours. Digital subtraction angiography revealed no appearance of left common carotid artery and left subclavian artery, accompanied by suspicious protrusion of aortic false lumen (figure, A, arrows). Aortic dissection was suspected and confirmed by CT angiography (figure, B and C), with emergent surgery following. Painless long-segmental aortic dissection should be considered during evaluation for IV thrombolysis and mechanical thrombectomy.

\section{Author contributions}

Dr. Qin: study concept and design, acquisition of data, drafting the manuscript. Dr. Tian: critical revision of the manuscript for important intellectual content, study supervision, obtaining funding.

\section{Study funding}

This work was supported by National Natural Science Foundation of China (81171157, 81873743).

\section{Disclosure}

The authors report no disclosures relevant to the manuscript. Go to Neurology.org/ $\mathrm{N}$ for full disclosures. 

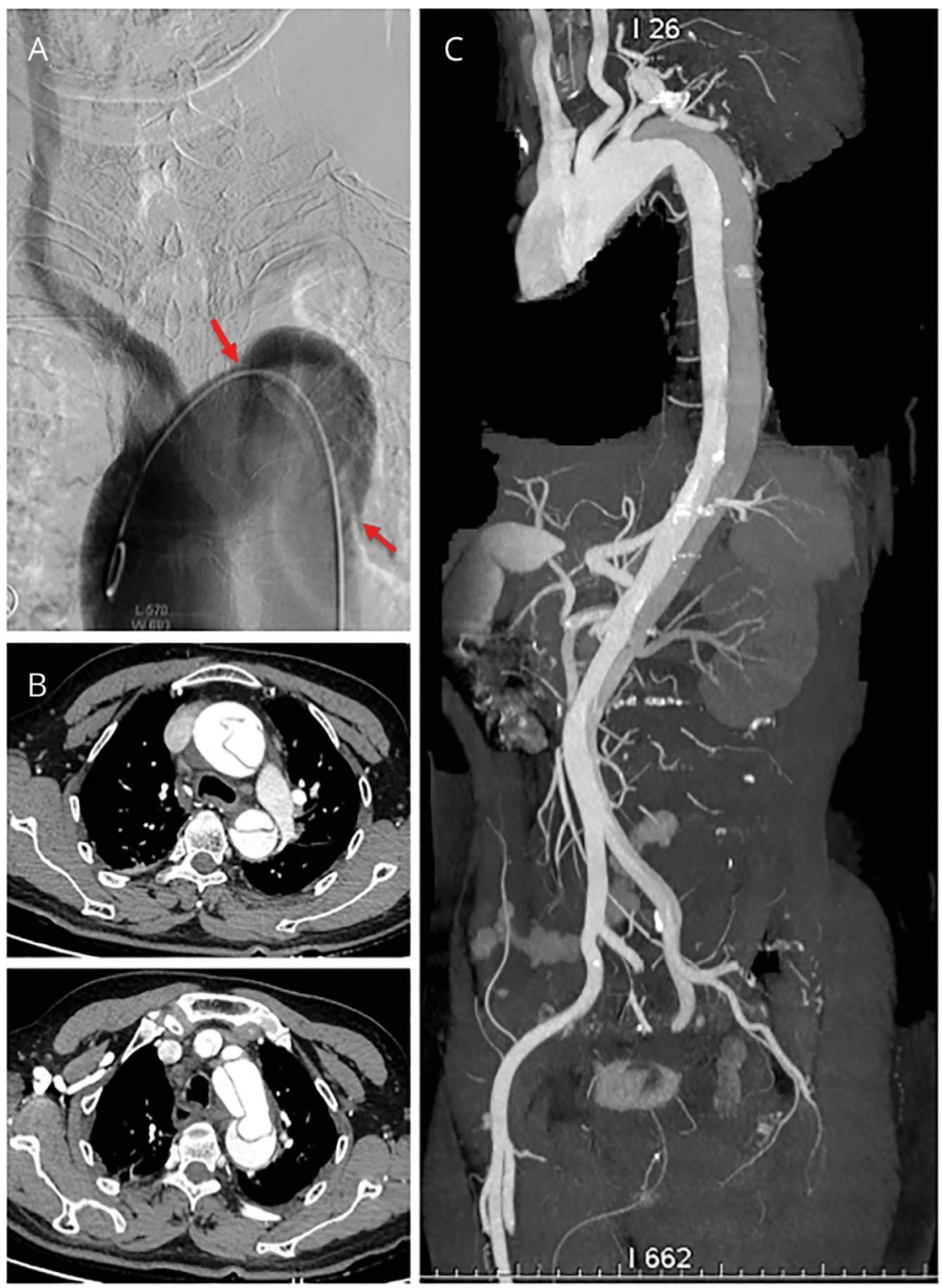

(A) No visualization of left common carotid artery and subclavian artery shown in DSA, but protrusion of aortic false lumen (arrows). (B) Double lumen and aortic intramural hematoma shown in CTA. (C) Type 1 of DeBakey system that originates in ascending aorta, propagates to aortic arch, descending aorta, and involves thoracoabdominal aorta and left common iliac artery.

\section{Subspecialty Alerts by E-mail!}

Customize your online journal experience by signing up for e-mail alerts related to your subspecialty or area of interest. Access this free service by clicking on the "My Alerts" link on the home page. An extensive list of subspecialties, methods, and study design choices will be available for you to choose from-allowing you priority alerts to cutting-edge research in your field! 


\title{
Neurology
}

\author{
Acute ischemic stroke due to painless long-segmental aortic dissection \\ Chuan Qin and Dai-Shi Tian \\ Neurology 2019;92;484-485 \\ DOI 10.1212/WNL.0000000000007049
}

This information is current as of March 4, 2019

\begin{tabular}{|c|c|}
\hline $\begin{array}{l}\text { Updated Information \& } \\
\text { Services }\end{array}$ & $\begin{array}{l}\text { including high resolution figures, can be found at: } \\
\text { http://n.neurology.org/content/92/10/484.full }\end{array}$ \\
\hline Subspecialty Collections & $\begin{array}{l}\text { This article, along with others on similar topics, appears in the } \\
\text { following collection(s): } \\
\text { All Cerebrovascular disease/Stroke } \\
\text { http://n.neurology.org/cgi/collection/all_cerebrovascular_disease_strok } \\
\text { e } \\
\text { Carotid artery dissection } \\
\text { http://n.neurology.org/cgi/collection/carotid_artery_dissection } \\
\text { CT } \\
\text { http://n.neurology.org/cgi/collection/ct }\end{array}$ \\
\hline Permissions \& Licensing & $\begin{array}{l}\text { Information about reproducing this article in parts (figures,tables) or in } \\
\text { its entirety can be found online at: } \\
\text { http://www.neurology.org/about/about_the_journal\#permissions }\end{array}$ \\
\hline Reprints & $\begin{array}{l}\text { Information about ordering reprints can be found online: } \\
\text { http://n.neurology.org/subscribers/advertise }\end{array}$ \\
\hline
\end{tabular}

Neurology ${ }^{\circledR}$ is the official journal of the American Academy of Neurology. Published continuously since 1951, it is now a weekly with 48 issues per year. Copyright () 2019 American Academy of Neurology. All rights reserved. Print ISSN: 0028-3878. Online ISSN: 1526-632X.

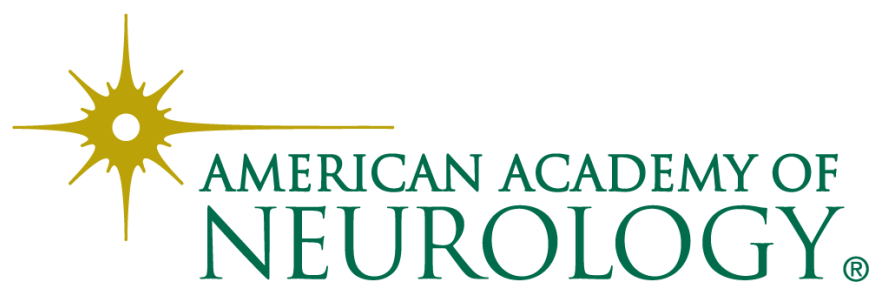

